\title{
PORCINE MALIGNANT HYPERTHERMIA - FAILURE OF DANTROLENE DOSE RESPONSE TO DIAGNOSE SUSCEPTIBILITY (HALOTHANE EFFECT)
}

\author{
E.H. Flewellen. T.E. Nelson and D.E. Bee
}

\begin{abstract}
Dantrolene. a skeletal muscle relaxant, has been proven prophylactic and therapeutic for malignant hyperthermia (MH) in swine. This study examined the feasibility of using a dantrolene dose response as measured by indirectly evoked foretoe twitch depression as a means to safely discriminate MH susceptibility in swine. The effect of halothane on the dantrolene response was quantified. Subjects were five Poland China malignant hyperthermia susceptible (MHS) and five Hampshire malignant hyperthermia resistant (MHR) swine. Dantrolene dose response was determined twice in each anaesthetized subject, once with thiopentone and subsequently with thiopentone and halothane. Dantrolene in incremental doses, $0.15 \mathrm{mg} \cdot \mathrm{kg}^{-1}$, was given to a cumulative dose of $2-3 \mathrm{mg} \cdot \mathrm{kg}^{-1}$. Under thiopentone anaesthesia, the dantrolene dose responses were similar in MHS and MHR animals. The presence of halothane augmented dantrolene twitch depression in MHS but not MHR animals when compared to their response under thiopentone. Under halothane, the MHS animals had significantly augmented dantrolene response compared to MHR pigs, but three MHS animals had developed the $\mathrm{MH}$ syndrome prior to receiving dantrolene. We conclude that dantrolene muscle relaxant dose response cannot be used as a diagnostic test for MHS in swine. Halothane augments dantrolene twitch depression in MHS swine.
\end{abstract}

VARIOUS TESTING METHODS have been proposed to discriminate malignant hyperthermia $(\mathrm{MH})$ susceptibility in man or swine: serum creatine phosphokinase, ${ }^{1.2}$ serum pyrophosphate, ${ }^{3}$ platelet aggregation, ${ }^{4}$ platelet metabolism, ${ }^{5}$ skeletal muscle contracture response, ${ }^{6.7}$ mitochondrial adenosine triphosphate depletion, ${ }^{8}$ sarcoplasmic reticulum vesicle calcium binding, ${ }^{9}$ skeletal muscle motor unit counting, ${ }^{10}$ neutron activation analysis for bone calcium, ${ }^{11}$ histology, ${ }^{12}$ and halothane-succinylcholine anaesthetic challenge. ${ }^{13}$ All have one or more major drawbacks for routine human testing; proven accuracy, availability, monetary cost, or unacceptable risk.

Dantrolene, a skeletal muscle relaxant has been shown prophylactic and therapeutic for $\mathrm{MH}$ in swine. ${ }^{14-18}$ The present study was undertaken to determine if a dantrolene dose response as measured by indirectly evoked muscle twitch tension could be used to determine $\mathrm{MH}$ suscepti-

E.H. Flewellen, M.D., Assistant Professor, Department of Anesthesiology; T.E. Nelson, Ph.D., Assistant Professor, Department of Anesthesiology; D.E. Bee. Ph.D., Associale Professor, Department of Preventive Medicine and Community Health, University of Texas Medical Branch, Galveston, Texas 77550.

Address for reprints: E.H. Flewellen, M.D., Department of Anesthesiology, University of Texas Medical Branch, Galveston, Texas 77550 .

Supported in part by U.S.P.H.S. NIH Grant 23875-01. bility safely in swine. The effect of halothane on the dantrolene dose response was also evaluated.

\section{MeTHOD}

Several weeks prior to these experimental procedures, malignant hyperthermia susceptibility (MHS) or resistance (MHR) was determined by in vitro caffeine and halothane skeletal muscle contracture testing in all subjects. ${ }^{19}$ Five purebred Poland-China litter mates of both sexes were found to be MHS and five purebred Hampshire litter mates of both sexes were found to be MHR. A dantrolene dose response curve was then determined twice in all subjects, first under thiopent oxygen anaesthesia and again 2 to 4 weeks later, under thiopentone-halothaneoxygen anaesthesia.

Indirectly evoked foretoe twitch tension was transduced and recorded as previously described ${ }^{20}$ Briefly, the forefoot was restrained in a plexiglass holder, the median nerve was stimulated through percutaneous wire electrodes at the elbow, and toe flexion tension was quantified. A dantrolene dose response was determined by assessing twitch tension depression to incremental intravenous bolus doses of $0.15 \mathrm{mg} \cdot \mathrm{kg}^{-1}$ to a cumulative dose of $2-3 \mathrm{mg} \cdot \mathrm{kg}^{-1}$. Dantrolene solution, $1 \mathrm{mg} / \mathrm{ml}$, was prepared fresh daily by dissolving $1 \mathrm{~g}$ of purified powder (Norwich- 
Eaton), $\mathrm{NaOH} 0.113 \mathrm{~g}$, mannitol $43.4 \mathrm{~g}$ in one litre of distilled water.

Initially, the MHS animals weighing $37 \pm 3 \mathrm{~kg}$ $( \pm S E)$ were anaesthetized with intravenous thiopentone $52 \mathrm{mg} \cdot \mathrm{kg}^{-1}( \pm 2 \mathrm{SE})$ prior to receiving dantrolene. After orotracheal intubation oxygen was provided at a flow of 4 litres/min in a semiclosed circle carbon dioxide absorption system. Arterial pressure (superficial femoral artery), electrocardiogram, percent peak expired carbon dioxide and rectal temperature were monitored continuously and recorded. Arterial gases and pH were determined before and after dantrolene was administered. During this series animals breathed spontaneously. In the halothane series the animals weighed $49.7 \mathrm{~kg}( \pm 3 \mathrm{SE})$ and thiopentone induction and tracheal intubation were accomplished as before and mechanical ventilation was instituted to maintain a constant peak expired carbon dioxide level. Halothane, 1.5 per cent initially, was then introduced into the breathing circuit and the end-tidal level was monitored and controlled to maintain a concentration of 0.8 per cent, approximating $1 \mathrm{MAC}$ halothane. Halothane was administered for one hour before a dantrolene dose response was initiated. Arterial blood gases and $\mathrm{pH}$ were determined before and after the dantrolene administration.

Initially MHR animals, weighing $14.2 \mathrm{~kg}( \pm 0.8$ $\mathrm{SE})$ were induced and maintained with thiopentone $55 \mathrm{mg} \cdot \mathrm{kg}^{-1}( \pm 1 \mathrm{SE}$ ) and oxygen was given (spontaneous respiration allowed) as in the MHS series. Electrocardiogram, per cent peak expired carbon dioxide and rectal temperature were monitored continuously. Halothane was administered just as to the MHS group. Dantrolene dose response was then determined. Subjects weighed $17 \mathrm{~kg}( \pm 0.7 \mathrm{SE}$ ). Arterial pressure and blood gases were monitored before and after dantrolene administration.

Variance of the means reported within this text are expressed as \pm standard errors of the means $( \pm S E)$. Evaluation of data for twitch depression was by analysis of variance procedures for repeated measures design. Specific simple effects comparing animals which received halothane to controls at each dantrolene concentration were studied within both MHR and MHS groups, as well as between groups. Simple effects were tested by pooling appropriate error terms from the analysis of variance and by adjusting degrees of freedom to ensure a conservative test. Values were determined significant at the $\mathrm{p} \leq 0.05$ level.
RESULTS

Results for the dantrolene dose responses are shown in Figures 1 to 4 . Statistical evaluation was carried out on only the steep portion of the dose response curves lying between a cumulative dantrolene dose of 0.15 and $1.50 \mathrm{mg} \cdot \mathrm{kg}^{-1}$.

The dantrolene dose response curves for MHS animals anaesthetized with thiopentone and similarly treated MHR animals are shown in Figure 1. The MHS group showed consistently higher mean values of twitch depression but significant differences were not evident at any dantrolene dose.

When halothane was administered to the MHS animals, the MH syndrome was observed in three of the five subjects prior to administration of dantrolene. $\mathrm{MH}$ was considered to have been triggered with the observation of mixed respiratory and metabolic acidosis, elevation of peak expired carbon dioxide and hind limb extensor rigidity. Dantrolene produced significantly greater twitch depression ( $p \geq 0.035$ ) in the presence of halothane at all doses except 1.35 and 1.50 $\mathrm{mg} \cdot \mathrm{kg}^{-1}$ (Figure 2).

The dantrolene dose response with halothane anaesthesia in the MHR animals is shown in Figure 3. Mean twitch depression was consistently higher in the presence of halothane compared to thiopentone treatment in the same animals. In contrast to the MHS group, these differences were not significant at any dantrolene dose. The largest means difference ( 9.6 per cent) occurred at the $1.2 \mathrm{mg} \cdot \mathrm{kg}^{-1}$ dantrolene dose level $(\mathrm{p}=$ $0.155)$.

Comparison of the dantrolene effect on twitch response in the two halothane treated, not triggered, MHS animals to the MHR halothane series resulted in significant mean differences ( $p$ $\leq 0.025$ ) for doses 0.30 through $1.05 \mathrm{mg} \cdot \mathrm{kg}^{-1}$ but not at the extremes of the response (Figure 4). Dantrolene also produced greater twitch depression in the three halothane triggered MHS subjects compared to the MHR halothane series, where highly significant differences ( $\mathrm{p} \leq .007$ ) existed for dantrolene doses 0.15 through $0.75 \mathrm{mg} \cdot \mathrm{kg}^{-1}$ (Figure 4). No significant difference was observed at the upper end of the response, at doses of 0.90 through $1.50 \mathrm{mg} \cdot \mathrm{kg}^{-1}$.

In the thiopentone series, between and among the MHS and MHR groups there was no difference for heart rate or end-tidal carbon dioxide before and after dantrolene (Table I). The MHS group had a significantly higher rectal tempera- 


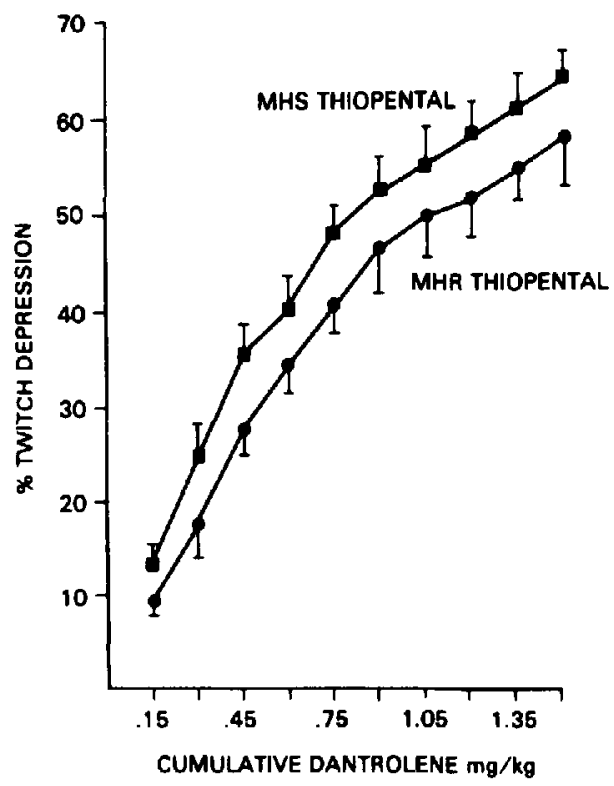

Figure 1. Cumulative effect of incremental dantrolene $(0.15 \mathrm{mg} / \mathrm{kg})$ on indirectly stimulated toe twitch in MHS (- $\longrightarrow$ ) and MHR (-) swine under thiopentone anaesthesia. Values are means for five animals and vertical bars are standard error for each mean.

ture at each measurement period but neither group changed with dantrolene administration (Table 1).

Within the MHS group there were significant differences in monitored parameters comparing the thiopentone to the halothane series (Table I). These differences were due to triggering of the MH syndrome in three of the halothane-treated animals.

Within the MHR group there were significant differences in heart rate comparing the thiopentone to the halothane series. The peak expired carbon dioxide or arterial carbon dioxide values do not suggest any differences in acid-base status (Table I).

\section{Discussion}

A dantrolene dose response cannot be used as a diagnostic test for $\mathrm{MH}$, based on the results of this study. We were unable to detect any significant difference in the response curves of the MHS and MHR subjects (Figure 1). It is of interest that per cent twitch depression for a given dantrolene dose was consistently higher in the MHS group and perhaps a larger series of animals would produce significant differences.

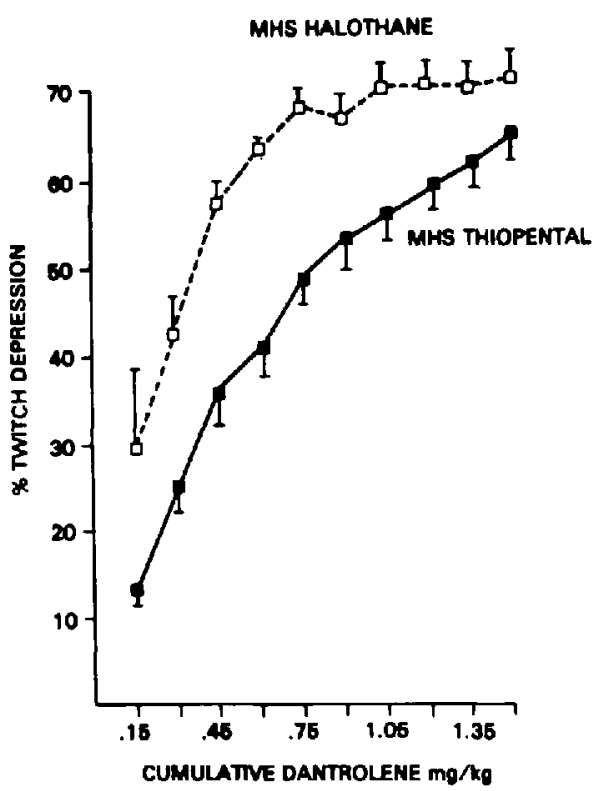

Figure 2. Cumulative effect of incremental dantrolene $\left(0.15 \mathrm{mg} \cdot \mathrm{kg}^{-1}\right)$ on indirectly stimulated toe twitch in the same MHS animals given halothane $\left(\left[\begin{array}{c}- \\ -\end{array}-\square\right)\right.$ or thiopentone ( $\square$ ) anaesthesia. Values are means for five animals and vertical bars are standard error for each mean.

However, these results do not suggest that a clear enough separation would exist to use the procedure as a diagnostic test for MH susceptibility. We speculate that $\mathrm{MH}$ skeletal muscle functions as normal muscle unless triggered by a stress, either physiological or pharmacological, and thus any diagnostic procedure of acceptable accuracy involving skeletal muscle must involve a triggering stimulus. Dantrolene does not stress $\mathrm{MH}$ skeletal muscle, but antagonizes the abnormal physiological MH state.

Dantrolene appears to cause skeletal muscle relaxation by blocking excitation-contraction (E-C) coupling by decreasing the amount of calcium released from sarcoplasmic reticulum. ${ }^{21,22}$ The aetiology of $\mathrm{MH}$ in skeletal muscle has not been determined but evidence points to a lesion in E-C coupling or sarcoplasmic reticulum function. ${ }^{19}$ Halothane, in clinical concentrations, has no significant effect on in vivo twitch tension in normal skeletal muscle. ${ }^{23}$ Thus we would not expect halothane to alter dantrolene effect in normal muscle (Figure 3). No significant effect of methoxyflurane on dantrolene dose responses was observed in sheep. ${ }^{24}$ Halothane does, however, augment twitch tension in skeletal muscle strips in vitro, and appears to produce this effect 


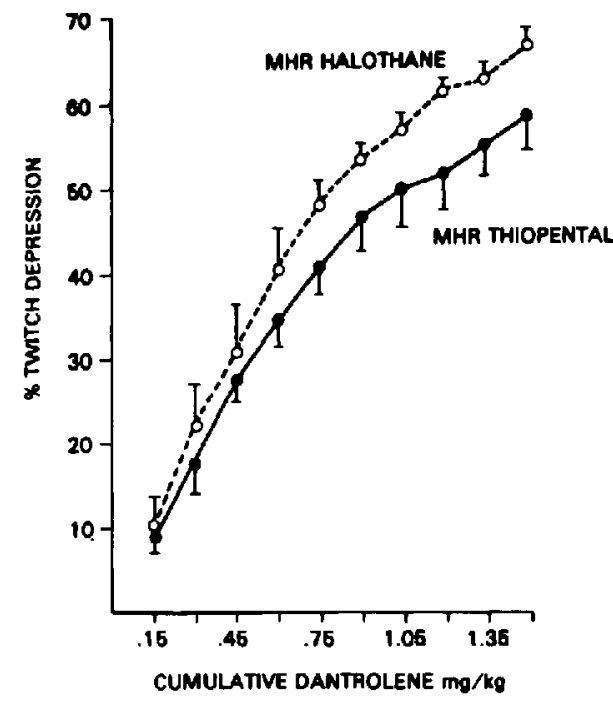

Figure 3. Cumulative effect of incremental dantrolene $\left(0.15 \mathrm{mg} \cdot \mathrm{kg}^{-1}\right)$ on indirectly stimulated toe twitch in the same MHR subjects given halothane $(O-$ - O$)$ or thiopentone $(\longrightarrow)$ anaesthesia. Values are means of five animals and vertical bars are standard error of each mean.

by acting on E-C coupling or sarcoplasmic reticulum. ${ }^{25}$ Abnormal contracture response in vitro to halothane in MHS skeletal muscle is used as a diagnostic procedure in the pig and in

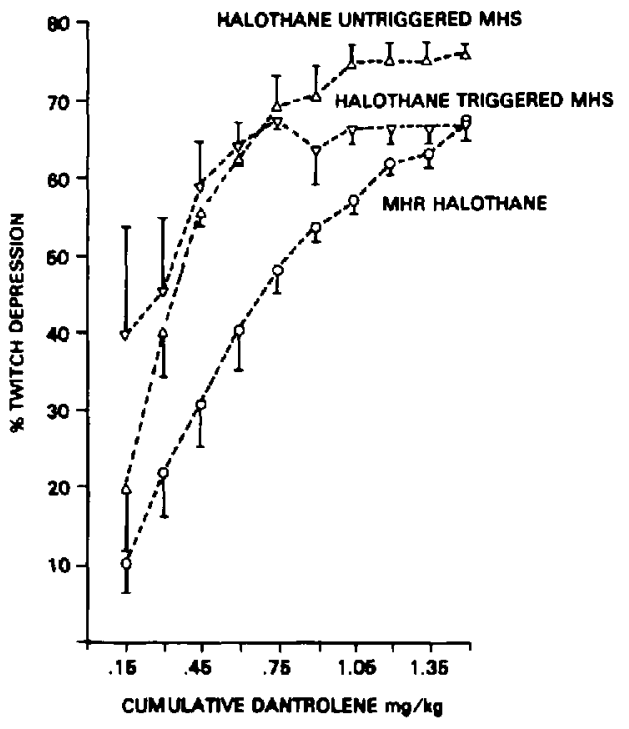

Figure 4. Cumulative effect of incremental dantrolene $\left(0.15 \mathrm{mg} \cdot \mathrm{kg}^{-1}\right)$ on indirectly stimulated toe Iwitch in two untriggered MHS $(\Delta-\cdots \Delta)$, three triggered MHS $(\nabla \cdots \nabla)$, and five MHR animals given halothane anaesthesia. Values are means of each group and vertical bars are standard error for each mean.

man. ${ }^{19.26}$ We cannot explain the significant augmentation of dantrolene twitch depression by halothane observed in MHS animals and it is reported as an interesting observation (Figure 2).

TABLE I

Effects of Dantrolene Administration in MHS and MHR Subjects ANaesthetized With THIOPENTONE OR THIOPENTONE-HaLothane $\left( \pm \mathrm{SE}_{\bar{R}}\right)$

\begin{tabular}{|c|c|c|c|c|c|}
\hline & & $\begin{array}{l}\text { MHS } \\
\text { thiopentone }\end{array}$ & $\begin{array}{c}\text { MHS } \\
\text { halothane }\end{array}$ & $\begin{array}{c}\text { MHR } \\
\text { thiopentone }\end{array}$ & $\begin{array}{c}\text { MHR } \\
\text { halothane }\end{array}$ \\
\hline $\begin{array}{l}\text { Heart rate } \\
\text { (beats/min) }\end{array}$ & $\begin{array}{l}\text { Pre-dantrolene } \\
\text { Post-dantrolene }\end{array}$ & $\begin{array}{l}119 \ddagger \pm 8 \\
114 \ddagger \pm 7\end{array}$ & $\begin{array}{l}146^{*} \pm 20 \\
132^{*} \pm 15\end{array}$ & $\begin{array}{l}115 \ddagger \pm 14 \\
112 \ddagger \pm 10\end{array}$ & $\begin{array}{l}99 \pm 7 \\
96 \pm 13\end{array}$ \\
\hline $\begin{array}{l}\text { Peak Expired } \\
\mathrm{CO}_{2}(\%)\end{array}$ & $\begin{array}{l}\text { Pre-dantrolene } \\
\text { Post-dantrolene }\end{array}$ & $\begin{array}{r}4.7 \pm 0.2 \\
4.6 \pm \pm 0.2\end{array}$ & $\begin{array}{l}5.7 \pm 1.6 \\
5.3 \pm 1.2\end{array}$ & $\begin{array}{l}4.5 \pm 0.15 \\
4.5 \pm 0.18\end{array}$ & $\begin{array}{c}\text { Not } \\
\text { measurcd }\end{array}$ \\
\hline $\begin{array}{l}\text { Rectal Tem- } \\
\text { perature }\left({ }^{\circ} \mathrm{C}\right)\end{array}$ & $\begin{array}{l}\text { Pre-dantrolene } \\
\text { Post-dantrolene }\end{array}$ & $\begin{array}{l}38.6^{*} \pm 0.4 \\
38.6^{*} \pm 0.4\end{array}$ & $\begin{array}{l}37.7^{*} \pm 0.7 \\
38.5^{*} \pm 1.3\end{array}$ & $\begin{array}{l}36.6 \pm 0.2 \\
36.3 \pm 0.1\end{array}$ & $\begin{array}{l}36.0 \pm 0.3 \\
35.6 \pm 0.3\end{array}$ \\
\hline $\begin{array}{l}\text { Arterial } \\
\text { Systolic } \\
\text { Pressure(kPa) }\end{array}$ & $\begin{array}{l}\text { Pre-dantrolene } \\
\text { Post-dantrolene }\end{array}$ & $\begin{array}{r}21.9 \neq \pm 1.9 \\
23 \neq \pm 0.8\end{array}$ & $\begin{array}{l}15.8 \pm 0.8 \\
16.9 \pm 1.3\end{array}$ & $\begin{array}{c}\text { Not } \\
\text { measured }\end{array}$ & $\begin{array}{l}15.7 \pm 0.7 \\
15.6 \pm 0.7\end{array}$ \\
\hline pH Arterial & $\begin{array}{l}\text { Pre-dantrolene } \\
\text { Post-dantrolene }\end{array}$ & $\begin{array}{l}7.49 \ddagger \pm 0.01 \\
7.48 \ddagger \pm 0.02\end{array}$ & $\begin{array}{l}7.26 \div \pm 0.1 \\
7.33^{*} \pm 0.1\end{array}$ & $\begin{array}{c}\text { Not } \\
\text { measured }\end{array}$ & $\begin{array}{l}7.51 \pm 0.02 \\
7.51 \pm 0.03\end{array}$ \\
\hline $\begin{array}{l}\mathrm{PaCO}_{2} \\
(\mathrm{kPa})\end{array}$ & $\begin{array}{l}\text { Pre-dantrolene } \\
\text { Post-dantrolene }\end{array}$ & $\begin{array}{r}5.4 \ddagger \pm 0.2 \\
5.6 \pm 0.3\end{array}$ & $\begin{array}{l}6.9 \ddagger \pm 1.7 \\
5.6 \dagger \pm 1.9\end{array}$ & $\begin{array}{c}\text { Nat } \\
\text { measured }\end{array}$ & $\begin{array}{l}5.3 \pm 0.4 \\
5.2 \pm 0.4\end{array}$ \\
\hline $\begin{array}{l}\mathrm{PaO}_{2} \\
(\mathrm{kPa})\end{array}$ & $\begin{array}{l}\text { Pre-dantrolene } \\
\text { Post-dantrolene }\end{array}$ & $\begin{array}{l}59.6 \neq \pm 0.5 \\
59.9 \pm 0.3\end{array}$ & $\begin{array}{l}49.2^{*} \pm 8.5 \\
48.0^{*} \pm 10.4\end{array}$ & $\begin{array}{l}\text { Not } \\
\text { measured }\end{array}$ & $\begin{array}{l}56.1 \pm 1.5 \\
59.3 \pm 2.3\end{array}$ \\
\hline
\end{tabular}

*MHS significantly different from MHR with similar treatment $(p<0.05)$.

†Significant change with dantrolene within a treatment $(p<0.05)$.

$\ddagger$ Significant difference between thiopentone and halothane treatment $(\mathrm{p}<0.05)$. 
A dantrolene-halothane exposure could not be used as a diagnostic test for $\mathrm{MH}$ in man because of unacceptable risk.

In conclusion, dantrolene-induced twitch depression cannot be used to discriminate MH susceptibility in swine. Halothane augments dantrolene skeletal muscle twitch depression in $\mathrm{MH}$ susceptible swine but does not in normal subjects. An accurate, low-risk, readily available, and inexpensive diagnostic procedure for $\mathrm{MH}$ susceptibility has yet to be discovered.

\section{ACKNOWLEUGEMENTS}

The authors wish to acknowledge the technical assistance of Ms. Pat Turk and Mr. John Finley.

Dantrolene sodium (Dantrium) powder was a gift of Norwich-Eaton Pharmacal.

\section{REFERENCES}

I. Brit I, B.A., Endrenyl L., Peters, P.L., Kwong, F.H.F. \& Kapituvic; L. Screening of malignant hyperthermia susceptible families by creatine phosphokinase measurement and other clinical investigations. Can. Anaesth. Soc. J. 23: 263-284 (1976).

2. Zsigmond, E.K., Starkweather, W.H., DuBOFF, G.S., et $a l$. CPK and malignant hyperthermia. Anesth. Analg. (Cleve) 51: 220-225 (1972).

3. Aldrete, J.A., Padfield, A., Solomon, C.C.\& RubriGH7, M. Possible predictive tests for malignant hyperthermia during anesthesia. J.A.M.A. 215: 1465-1469 (1971).

4. Zsigmond, E.K., Penner, J. \& Kothary, S.P Normal erythrocyte fragility and abnormal platelet aggregation in MH families: a pilot study. 2nd International Symposium on Malignant Hyperthermia. Ed. Aldrete, J.A., Britt, B.A. Grune and Stratton, New York, pp. 213-219 (1978).

5. Solomons, C.C. TAN, S. \& Alurtte, J.A Platclet metabolism and malignant hyperthermia. 2nd International Symposium on Malignant Hyperthermia. Ed. Aldrete, J.A. \& Britt, B.A. New York, Grune and Stratton, pp. 221-225 (1978).

6. Nelsun, T.E., Austin, K.L. \& Denborough M.A. Screening for malignant hyperpyrexia. Br. J. Anaesth. 49: 167-171 (1977).

7. Kalow, W., Britt, B.A. \& Peters, P. Rapid simplified techniques for measuring caffeine contraction for patients with malignant hyperthermia. 2nd International Symposium on Malignant Hyperthermia. Ed. Aldrete, J.A. \& Britt, B.A., New York, Grune and Stratton, pp. 339-350 (1978).

8. Britt, B.A., ENDRenyi. L, Kalow, W., et al. The adenosine triphosphate (ATP) depletion test: comparison with the caffeine contracture test as a method of diagnosing malignant hyperthermia susceptibility. Can. Anaesth. Soc. J. 23: 263-284 (1976).
9. Ryan, J.F., SNeter, F.A. \& Donion, J.V. I vitro measurement of calcium transfer across the sarcoplasmic reticulum membrane as a predictor of malignant hyperthermia. Abstracts of Scientific Papers. Am. Soc. Anesth., pp. 431-432 (1976).

10. Brit7, B.A., Mc Comis, A.J., ENisRteryl. L. \& KaLOW, W. Motor unit counting and the caffeine contracture test in malignant hyperthermia. Anesthesiology 47:490-497 (1977).

I1. BrITT, B.A., HARrISUN, J.E. \& MCNt1L, K.G. II vivo neutron activation analysis for bone calcium (INAA) in malignant hyperthermia susceptible patients. Can. Anaesth. Soc. J. 26: 117-124 (1979).

12. Harriman, D.G.F., Ellis, F.R., Franks, A.J.\& SUMNER, D.W. Malignant hyperthermia myopathy in man: an investigation of 75 families. 2nd International Symposium on Malignant Hyperthermia. Ed. Aldrete, J.A. \& Britt, B.A., New York, Grune and Stralton, pp. 67-87 (1978).

13. Grontert, G.A. \& Thtyt, R.A. Halothaneinduced porcine malignant hyperthermia. Anesthesiology 4 : 36-43 (1976).

14. Harrison, G.G. Control of the malignant hyperpyrexic syndrome in MHS swine by dantrolene sodium. Br, J. Anaesth. 47: 62-65 (1975).

15. Gronert, G.A., Mildt, J.H. \& Thtyt., R.A Dantrolene in porcine malignant hyperthermia. Anesthesiology 44: 488-495 (1976).

16. Hall, G.M, Lucke, J.N. \& ListitR, D. Treatment of porcine malignant hyperpyrexia. Anaesthesia $32: 472-474$ (1977).

17. Harrison, G.G. The prophylaxis of malignant hyperthermia by oral dantrolene sodium in swine. Br. J. Anaesth, 49: 315-317 (1977).

18. Kerr, D.D., Wingard, D.W. \& Gatz, E.E. Prevention of porcine malignant hyperthermia by oral dantrolene. 2nd International symposium on malignant hyperthermia. New York, Grune \& Stratton, Ed. Aldrete, J.A. \& Britt, B.A., pp. 499-507 (1978).

19. Nelson, T.E. Excitation-contraction coupling: a common etiologic pathway for malignant hyperthermia susceptible muscle. 2nd International Symposium on Malignant Hyperthermia. Ed. Aldrete, J.A. \& Britt, B.A. New York, Grune \& Stratton, pp. 23-36 (1978)

20. Nelson, T.E. \& FltwillteN, E.H. Rationale for dantrolene versus procainamide for treatment of malignant hyperthermia. Anesthesiology 50 : 118-122 (1979).

21. El.lis, K.O. \& CARPenter, J.F. Studies on the mechanism of action of dantrolene sodium. Naunyn-Schmiedeberg's Arch. Pharmacol. 275: 83-94 (1972).

22. Murgan, K.G. \& Bryant, S.H. The mechanism of action of dantrolene sodium. J. Pharm. and Exp. Ther. 201: 138-147(1977).

23. KATZ, R.L. \& Gissen. A.J. Neuromuscular and electromyographic effects of halothane and its interaction with d-tubocurarine in man. Anesthesiology 28: 564-567 (1967).

24. Ellis, K.O., WhSSels, F.C.\& Carpentter, J.F. Effects of intravenous dantrolene sodium in respiratory and cardiovascular functions. J. Pharm. Sci. 65: 1359-1364 (1976).

25. Nelson, T.E. \& Denborough, M.A. Studies on 
normal human skeletal muscle in relation to the pathopharmacology of malignant hyperpyrexia. Clin. Exp. Pharmacol. Physiol. 4: 315-322 (1977).

26. Ellis, F.R., KLANEY, N.P. Harrimian, D.G.F.,
Sumner, D.W., Kyti-Mt.NSAH, K., TyrRl:Ll. J.H., Hargriaves, J.B., Parikh, R.K. \& Mul.Roority, P.L. Screening for malignant hyperpyrexia. Br. Med. J. 3: 559-561 (1972).

\section{RÉSUMÉ}

Le dantrolène, un relaxant du muscle squelettique, s'est avéré efficace pour la prévention et le traitement de l'hyperthermie maligne chez le porc. Les auteurs ont étudié la possibilité d'utiliser cet agent comme moyen de dépistage de la susceptibilité à l'hyperthermie maligne en mesurant la réponse en tension de l'orteil antérieur à l'adninistration du dantrolène. L'influence de l'halothane sur cette réponse a également été étudiée. Cinq porcs susceptibles à I'hyperthermie maligne et cinq porcs non susceptibles ont élé utilisés. La réponse au dantrolène a été mesurée à deux reprises chez chaque animal anesthésié, la première fois au thiopenthal et la seconde au thiopenthal et halothane. La dose de dantrolène était progressivement augmentée de $0.15 \mathrm{mg} \cdot \mathrm{kg}^{-1}$ jusqu'à un total cumulatif de 2 à $3 \mathrm{mg} \cdot \mathrm{kg}^{-1}$. Sous thiopenthal, l'effet du dantrolène était le même chez les animaux susceptibles d'hyperthermie maligne que chez ceux résistant à cettc pathologie. Les animaux susceptibles avaient une plus forte réponse au dantrolène que les normaux lorsque l'on ajoutait l'halothane au thiopenthal, mais trois animaux présentèrent une hyperthermie maligne avant que l'on ait eu le temps de leur administrer le dantrolène. Il est conclu que la réponse à une dose de dantrolène ne peut être utilisée comme test de l'hyperthermie maligne chez le porc et que l'halothane augmente la dépression de la contracture produite par le dantrolène. 